\title{
The FOMC in 1974: Monetary Policy During Economic Uncertainty
}

\author{
SUSAN R. ROESCH
}

URING 1974 many uncertainties existed in the implementation of monetary policy. Foremost was the likely course of economic activity during the year. Economic forecasters, both private and government, badly misjudged actual economic developments. Forecasts throughout the year were quite varied and were frequently revised.

Another uncertainty involved the question of the appropriate rate of growth of the monetary aggregates. Some analysts viewed the downturn in output to be the result of supply constraints, and concluded that, in view of the accelerating rate of inflation, a slower rate of growth of money was appropriate. Other analysts held the view that the cause of the decline in real output was inadequate aggregate demand, and thereby urged more rapid monetary expansion.

The Federal Open Market Committee (FOMC) was thus faced with an unusually high degree of uncertainty in adopting monetary actions which were considered consistent with the agreed-upon goals for the economy. ${ }^{1}$ Monetary actions were taken which the Committee considered consistent with long-run objectives for monetary growth. Specific instructions were given to the Trading Desk to achieve, over periods of two months, growth of RPDs and the money stock (both $M_{1}$ and $M_{2}$ ) within specified ranges, and to maintain the Federal funds rate within specified limits until the subsequent meeting of the Committee." Money, however, frequently did not grow as was planned, which was another problem which plagued the FOMC throughout much of 1974.

This article first reviews forecasts of private and government economists, including the staft of the FOMC, throughout the year and traces the gradual deterioration in the outlook. Next, the question of uncertainty regarding the appropriate growth of the money stock is examined. Finally, the uncertainty

\footnotetext{
1The "Record of Policy Actions", which in 1974 was released to the public usually three months after each FOMC meeting and subsequently published in the Federal Reserve Bulletin, contained a brief outline of observed and projected economic conditions as well as a description of the monetary actions taken by the FOMC.

$\mathrm{M}_{\mathrm{t}}$ is demand deposits and currency held by the nombank public. $M_{2}$ is $M_{1}$ plus net time deposits. Becatse of the dis continuities of the series, reserves available to support private nonbank deposits (RPDs) are omitted from the discussion presented here.
}

regarding the response of the money stock to policy actions is discussed.

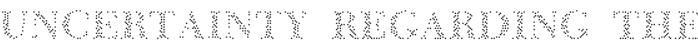

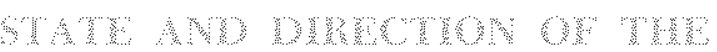

$$
\begin{aligned}
& \text { BaOMH }
\end{aligned}
$$

\section{trathe Pretichms}

In the closing days of 1973 , forecasters were hedging their predictions more than usual because of the uncertain impact of the oil embargo and the associated "energy crisis." Most economists believed that the U. S. economy would grow more slowly in 1974 than it did in 1973, with most of the rise in gross national product (GNP) accounted for by prices rather than output. This was the concensus among the eleven economists assembled by the Conference Board late in 1973, and was typical of the forecasts of other leading economists.

While many foresaw much slower growth in output, on average, in 1974, few accurately predicted the extent of the actual decline. The Conference Board forecasted a rise in nominal GNP of just under 8 percent -5.3 percent in prices and 2.3 percent in real growth. Actual growth in GNP during the year ending fourth quarter 1974 was 6.5 percent - a 12 percent increase in prices and a 5 percent decline in real output.

Herbert Stein, then Chairman of the President's Council of Economic Advisers, predicted late in 1973 that unemployment would approach 6 percent in 1974, but not exceed that figure. James Meigs, then vice president and economist for Argus Research Corporation, projected an unemployment rate that would peak at about 5.5 percent. The actual level of unemployment in December 1974 was 7.1 percent of the labor force.

Most people were forecasting a slowdown rather than a recession for 1974. In December 1973 the FOMC staff was also inclined to accept this view, but in less specific terms: "Staff projections suggested that economic activity would weaken further in the first half of 1974 and that prices would rise appreciably, in part because of curtailment in oil supplies."

As the first quarter was drawing to a close, there was still no agreement among private economists as 
to the extent of the slowdown in the economy. Lionel D. Edie \& Co., Investment Counselors and Economic Consultants, estimated that real output in the first quarter would decline at a 6.6 percent anmul rate, while econometric forecasters at Georgia State University anticipated a decline of only 1 percent.

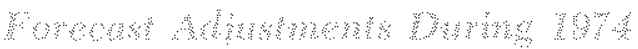

Projections made in March for the second half of 1974 continued to substantially overestimate growth in the economy. Wharton economists had one of the "gloomiest" views, but still considerably understated price increases and overstated real economic growth. Recession would persist in the first half of the year, according to Wharton, but during the second half there would be real growth of about 1 percent. Other private forecasters were even farther off-target than Wharton. Data Resources expected a substantial dip in first quarter real product growth, but forecasted a rise at a 1.9 percent rate in the second quarter, and by fourth quarter they foresaw real output rising at a 6.4 percent annual rate.

The FOMC staff projections at the March meeting were somewhat more cattious than the other projections cited above. "Staff projections, like those of 4 weeks earlier, suggested that real output would change little in the second quarter and that the rise in prices would remain rapid." The termination of the embargo on oil shipments to the United States was expected to have no more than a marginally expansive impact on overall real ontput until the summer, although the automobile and housing markets were expected to strengthen sooner.

At midyear most forecasters were still apprehensive about the prevaling economic situation. GNP had increased at only a 6 percent annal rate during the first half of 1974 , with prices rising at almost an 11 percent rate and real output declining at over a 4 percent annual rate.

Most private forecasters continued to believe that real output would rise slightly and that the rate of increase in prices would slow somewhat during the remainder of the year. First National City Bank predicted a rise in the unemployment rate to possibly 6 percent by the end of 1974, with no growth in output during that period.

At the July meeting, the FOMC staff presented projections suggesting that in the second half of the year "real economic activity would grow at a minimal pace and that prices would increase less rapidly than in the first kalf." Since an apturn in residential con- struction was no longer expected, and a somewhat greater decline in net exports was now anticipated, real economic activity was projected to grow somewhat less than had been projected four weeks earlier.

In early August, Gerald Ford replaced Richard Nixon as President. The change in Administrations appeared to give the country a psychological lift, especially since President Ford had indicated that high priority would be given to bringing inflation under control.

Despite the psychological lift, the Argus Research Corporation commented in exrly August that "we now expect the consumer price index to be rising at a 10.3 per cent annual rate in the fourth quarter," instead of the 7.2 percent forecasted earlier. Michael Evans, chief economist for Chase Econometrics, contended that recession "will stay with us for the rest of the year."

Even as late as mid October, forecasters were still underestimating inflation and overstating the level of economic activity. Herbert $\mathrm{E}$. Neil, Jr, vice-president and economist at Harris Trust and Savings Bank, Chicago, forecasted an memployment rate of 6 percent of the work force by the end of 1974 . He also predicted that automobile sales would decline sharply in the fourth quarter.

Even as pessimistic as they appeared throughout the year, most forecasters were continually more optimistic than proved to be warranted. Special factors causing the declines in real output were accurately estimated by few, if any, economists. Thus, throughout 1974 the Federal Open Market Committee, in establishing monetary policy, was faced with great uncertainty regarding the economic outlook.

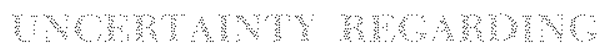

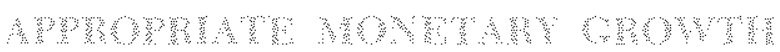

The inaccuracies in economic forecasts left many uncertainties regarding appropriate growth of monetary aggregates during 1974. Much of the disagree ment among analysts regarding growth of the aggregates stemmed from disagreement regarding the basic causes of the inflation-recession situation. Those who believed the contraction in output was induced by insufficient demand called for more rapid monetary growth. These analysts based their judgment on movements in such measures as real money balances, income velocity, and market interest rates.

Another school of thought contended that for the most part the recession was supply-induced; continu- 


\section{Organization of the Committee in 1974}

The Federal Open Market Committee (FOMC) consists of the seven members of the Federal Reserve Board of Govemors and five of the twelve Federal Reserve Bank Presidents. The Chairman of the Board of Governors is also by tradition, Chaiman of the Conmittee. The President of the New York Federal Reserve Bank is a permanent member of the Committee and, also by trodition, is its Vice Chamman. All other Federal Feserve Bank Presidents attend the meetings and present their views, but votes may be cast by only four of these Presidents, who serve as nembers for one-year terms on a rotation basis

Members of the Board of Governors for 1974 in Cluded Chairman Arthur $F$ Bums, Vice Chaiman George W. Mitehell, Andrew F, Brimmer, Jeffrey $M$ Bucher, Robert C, Holland, John E, Sheehan, and Henry $\mathrm{C}$. Wallich Mr. Wallich assumed his duties March 8 , replacing I Dewey Dane whose term ex pired January 31 On October 29 . Philip E Coldwell succeded Andrew F. Brimmer, who resigned effective August 31 from the Board of Governors In addtion to Alfred Hayes, President of the Federal Reserve Bank of New York, the following Presidents served on the Committee during January and Febrtary 1974: John J Balles (San Francisco), Darryl R, Francis ( $S t$ Louis), Robert D Mayo (Chicago), and Frank E, Moris (Boston), In Mareh the Committee was reorganized and the four rotating positions were filled by the fol lowing members, Robert P. Black (Richmond), George H. Clay (Kansas City), Monroe Kmbrel (Atlanta), and Willis I Winn (Cleveland).

The Committee met regularly once each month during 1974 to discuss economic trends and to decide upon the future course of open market operations. As in previous years, occasional telephone or telegram consultations were held between regular meetings. Additional policy actions for subsequent weeks and months were generally discussed at these interim meetings. During each regular meeting, a directive was issued to the Federal Reserve Bank of New York stating the general economic goals of the Committee and providing general guidelines as to how the Manager of the System Open Market Account $^{1}$ at the New York Federal Reserve Bank should conduct open market operations to achieve these goals. Each directive contained a shot review of economic data considered and the general economic goals sought by the Committee. The last paragraph gave operating instructions to the Account Manager. These instructions were stated in terms of bank reserve and money market conditions which were considered consistent with the achievement of desired growth rates of monetary aggregates. Any. special factors, such as Treasury financing operations, were also taken into account.

1The Manager of the System Open Market Account may be referred to as the "Account Manager" and the Trading Desk of the New York Felleral Reserve Bank as the "Desk."
The decisions on the exact timing and amount of daily buying and selling of securities in fulfilling the Committee's directive are the responsibility of the System Open Market Account Manager at the Trading Desk of the New York Bank. Each morn ing, the Account Manager and his staff decide what open market operations, if any, are to be undertaken that day. In developing this program, money and credit market conditions and aggregate targets desired by the Committee are considered, as well as other factors which may be of concem at that time. Each moning in a conference call, the Account Manager informs one voting President and staff members of the Board of Governors about present market conditions and open market operations which he proposes to execute that day, Other members of the Committe are informed of the datly program by wire summary.

A summary of the Committees actions is presented to the public in the "Record of Policy Actions" of the Federal Open Market Committee In 1974 the "Record" for each meeting was released about 90 days after the meeting and was published in both the Ammual Report of the Board of Governors of the Federal Reserve System in spring and in the Federal Reserve Bulletin each month The "Recond for each meeting generally includes:

1) a staft summary of recent economic developments, such as prices, employment industrial production, and components of the national income accounts, projections concerning real output growth for one or two quarters ahead; and prospective financial developments;

2) a discussion of the U.S. balance of payments and international financial developments;

3) a discussion of interest rate movements;

4) a discussion of open market operations and growth of reserve aggregates since the last meeting;

5) a discussion of the movements of monetary agw gregates such as $\mathrm{M}_{1}$ and $\mathrm{M}_{2}$, and the adjusted credit proxy; ${ }^{2}$

6) conclusions of the FOMC;

7) a policy directive issued by the FOMC;

8) a list of the voting position of members and any dissenting comments;

9) a description of any actions and consultations that may have occurred between the regularly scheduled meetings.

\footnotetext{
${ }^{2} \mathrm{M}_{1}$ refers to the money stock, defined as private demand deposits plus currency in the hands of the nonbank public. Mz refers to money stock plus net time deposits. Net time deposits are defined as total deposits at all commercial banks minus large time certificates of deposit at large weekly reporting commercial banks. Adjusted credit proxy is defined as member bank deposits subject to reserve requirements plus bank-related commercial paper, Eurodollar borrowings of U, S. banks, and certain other nondeposit items.
} 
ing inflation indicated excessive aggregate demand, and therefore called for less rapid monetary growth. They cited the many shocks to the economy which occurred during the year and in the immediately preceding year as factors limiting the ontput of goods and services.

The January 1974 issue of First National City Bank's Monthly Economic Letter highlighted the conflict faced by policymakers last year: "To prevent inflation from making the slowdown or recession even deeper in this country, the growth of the money stock would have to be accelerated to a rate substantially higher than that of 1973. More rapid monetary expansion, to be sure, promotes and validates inflation." First National City Bank also pointed out that the task of the Federal Reserve was especially difficult during the cyclical currents that existed then. They contended that, historically, undue monetary expansion during recessions has proved to be the "ultimate folly." Also, in the short run, a recession caused by supply constraints would probably not respond to rapid growth in the money supply.

This conflict of views was evident in the FOMC deliberations. For example, in their dissents to the directive adopted at the February 20 meeting, Governors Bucher and Sheehan and President Morris ". . . expressed concem about current and prospective weakness in aggregate economic demands." On the other hand, President Francis in dissenting ". . expressed the view that the over-all economic situation was stronger than suggested by the staff projections and that inflation remained the major long-term economic problem."

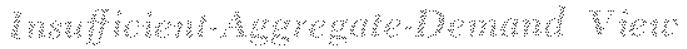
o Downtrom

One group of observers advised that rapid money growth was appropriate last year because their analy. ses led them to attribute the downturn to insufficient growth of agrregate demand. A continuing decrease in real money balances, a slower growth in income velocity, and high market interest rates were cited by various analysts as evidence in support of the weakaggregate-demand view.

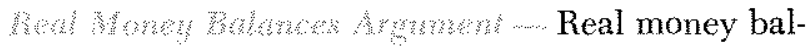
ances (money stock divided by some index of the price level, $\mathrm{M} / \mathrm{P}$ ) decreased in the last half of 1973 and continued to decrease throughout 1974. Some analysts argued that such a decrease had a marked retarding effect on growth of aggregate demand last year. Their argument is as follows: People desire to hold some given level of "real" money balances as part of their asset portfolio. When actual seal money balances decline, and if there is no clange in desired real balances, spending on goods and setvices will be restricted in an attempt to restore real money bal ances to the desired level. Ffforts to do so would cause a decline in total spending, output, and, ultimately, the price level. The proponents of this view argued such was the case in 1973 and 1974 .

A decline in real money balances can occur through changes in either the numerator or denominator of this expression; either the growth of nominal money balances slows relative to the rate of change of prices, or the rate of inflation accelerates while growth of the money stock is relatively steady. During most of 1974 the decline in the ratio of the money stock to the price level was due to prices accelerating sharply relative to growth of the money stock. In other periods since World War II when real money balances declined preceding a recession, the money stock was declining or was growing at a rate slower than previously, but prices were relatively stable.

The real balance argument presents a fundamental policy dilemma. On the one hand, in order to avoid a severe economic contraction the monetary authorities should increase the money stock rapidly so as to rem store growth in real balances. On the other hand, since the growth of money determines the rate of inflation, an infusion of "unwanted" money would only add fuel to the inflation. ${ }^{3}$ In essence, the crucial question is whether an observed decline in real balances is the result of a voluntary action on the part of the public.

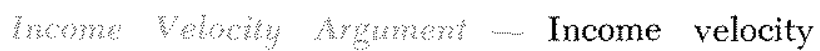
(nominal GNP divided by the money stock) in 1974 grew at a rate about half that of 1973 . A group of analysts argued that given actual money growth, this decline in velocity growth depressed growth of aggregate demand. This argument is similar to the real money balances one, in which these measures are used as indicators of slackening aggregate demand. Since both measures incorporate prices and money, they often lead to similar conclusions.

Those who advance the velocity argument assert that velocity is a proxy measure for desired money balances. A slower growth of velocity is said to re-

\footnotetext{
3 For further explanation see Denis S. Karnosky, "Real Money Balances: A Misleading Indicator of Monetary Policy Actions," this Review (February 1974).
} 
flect an increase in desired money balances relative to income. It is argued that if the level of actual money balances is constant, but individuals want to increase their holdings of money, they will decrease their spending on goods and services so as to achieve their desired level of money balances.

The slower growth in velocity last year represented, according to proponents of this view, an increase in desired money balances relative to income; thus a more rapid growth in the money supply should have occurred last year if growth of aggregate demand was not to slow down. On the other hand, the slower growth in measured velocity during 1974 may have been a temporary phenomenon resulting from the increased economic and political uncertainty prevailing in this period. In such a case, a faster growth in money wotuld have led to even greater inflation as velocity returned to its previous trend.

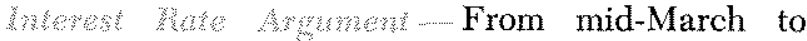
early July, market interest rates climbed at a steady pace. Then, from midyear through the end of the year, short-term interest rates declned sharply, while long-term interest rates fell very slowly. A large group of economists argued that such a rise in interest rates, particularly long-term rates, represented an overly restrictive monetary policy tending to curtail future aggregate demand. As a result of this type of analysis, they argued for faster money growth in order to achieve lower interest rates than the levels prevailing during early 1974.

A counter argument is that the rapidly rising long. term interest rates in the first half of 1974, and their failure to decline significantly in the last half of the year, was primarily the result of a high and increasing rate of inflation which led to a larger inflation premium in market interest rates. This argument contended that faster money growth would add to the already excessive rate of inflation and, ultimately, result in even higher interest rates.

The proponents of the interest rate view were not impressed by the inflation premium view of high market interest rates. For example, in analyzing monetary policy in mid-1974 Professor James Tobin of Yale University stated, "I have only tried to indicate that the policy [of the Federal Reserve] contains more bite and cost and risk than one might suspect from superficial comparisons of interest rates and rates of inflation."4

"James Tobin, "Inflation, Interest Rates, and Stock Values," The Morgan Guaranty Survey (July 1974), pp. 4-7.

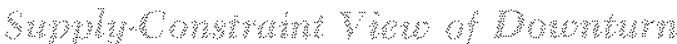

In contrast to those holding the insufficient-aggregate-demand view of the downturn, another group of analysts argtued that aggregate demand was strong, as indicated by the accelerating inflation, but there existed many special factors tending to limit production of goods and services last year. This group argued that the downtum mainly reflected the influence of these supply factors during the first three quarters of the year.

Early in 1974, Chairman Arthur F. Burns presented the following analysis to the Joint Economic Committee:

The current economic slowdown, however, does not appear to have the characteristics of a typical business recession. To date, declines in employment and production have been concentrated in specific industries and regions of the country rather than spread broadly over the economy. In some major sectors the demand for goods and services is still rising. Capital spending plans of business firms remain strong and so do inventory demands for the many materials and components in short supply.

Chairman Burns then concluded:

A highly expansive monetary policy would do little to stimulate production and employment; but it would run a serious risk of rocking fnancial markets, of causing the dollar to depreciate in foreign exchange markets, and of intensifying our already dangerous inflationary problem.

At midyear President Darryl R. Francis, in an address to the Steel Plate Fabricators Association, argued that

... the economy is fundamentally very strong and there is more than adequate aggregate demand to promote real expansion. I view the slower growth in real output after the first quarter of 1973 as being attributable to the economy operating "flat-out" at full capacity in an environment where price and wage controls severely reduced the efficiency of the market system in allocating resources in the production process.

I do not see how the existence of wide-spread shortages of commodities and sharply rising prices can be viewed as characteristics of weak aggregate demand. The sharp drop in real output in the first quarter of this year was clearly the result of the oil boycott and related developments such as the trickers' strike, the allocation program, and the presence of controls on both prices and resource movements. Only a few industries were affected and all of them were energy related. Furthermore, unemployment in the first few months of this year was much smaller than one would have expected if the sharp drop in real output had been widespread and had resulted from fundamental weakness in the economy. 


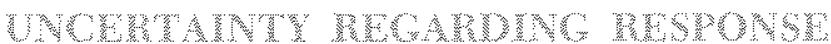

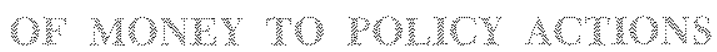

Throughout the year the FOMC outlined its objectives concerning open market operations to the System Account Manager in the domestic policy directive issued at each meeting. The policy consensus and operating instructions, as well as the dissents for each meeting, are presented in Exhibit I. Specifically, the directions to the Desk were in terms of a Federal funds range during the intermeeting period and a range of tolerance for growth of $M_{1}$ and $M_{2}$ over the subsequent two months. These ranges were considered to be consistent with the FOMC's longer-run growth of money. The ranges set at each meeting, in addition to the actual growth of the variables, are shown in accompanying charts, p. 10.

Growth of $M_{1}$ was very rapid in the first half of 1974, but decelerated sharply in the second half. Short-run growth of money was frequently outside the specified ranges during the last half of the year, which raised questions regarding the degree of responsiveness of money stock to Federal Reserve actions.

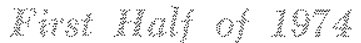

At the January meeting of the FOMC, a staff analysis suggested that "growth in the demand for money over the first half of 1974 was likely to be somewhat greater than had been expected earlier." It appeared likely to the Committee that if $\mathrm{M}_{1}$ were to grow at a rate consistent with the longer-run objectives for monetary aggregates ${ }^{\overline{ }}{ }^{\overline{1}}$ money market conditions would tighten somewhat in the period immediately ahead. In response to these observations, the Committee adopted ranges of tolerance for growth rates of $M_{1}$ and $M_{2}$ over the January-February period of 3 to 6 percent and 6 to 9 percent, respectively. They also decided that "in the period until the next meeting the weekly average Federal funds rate might be permitted to vary in an orderly fashion from as low as $8^{3 / 4}$ per cent to as high as 10 per cent, if necessary, in the course of operations."

Noting the decline in $M_{1}$ in January, the Committee adopted ranges of tolerance for the FebruaryMarch period which were considerably greater than the ranges set for the January-February period. Two special consultations occurred between the February and March meetings. On March 1 , "a majority of the available Committee members concurred in the Chair-

5The longer run objectives for the monetary aggregates, are never explicitly stated in the "Record of Policy Actions." man's recommendation that, in light of the marked rise in short-term interest rates that had occurred since the February meeting and of the highly sensitive state of the financial markets, reserve-supplying operations for the time being should be conducted in a manner expected to be consistent with maintenance of the Federal funds rate at about the 9 per cent level that had prevailed over the preceding 3 weeks."

On March 11 the FOMC consensus was that "in response to evidence that strong growth in the monetary aggregates was persisting, ... the Account Manager was instructed to proceed very cautiously in operations thought likely to be consistent with a rise in the weekly average Federal funds rate above 9 per cent."

The regular meeting in March was the first following the election of new voting members of the FOMC. The staff analysis suggested the following at this meeting: ". . . estimates of the likely strength of money demands over the spring and summer and of the relationships between monetary growth rates and market interest rates were subject to larger margins of error than usual because of the greater uncertainty attached to projections of nominal GNP ...." The ranges of growth for the aggregates for the March-April period were lower than for the February-March period. The Federal funds range established at the March meeting was higher than the range set at the February meeting.

While the Desk was supplying reserves to maintain the Federal funds rate as desired, the money stock was expanding at an extremely rapid rate. During the two months prior to the April FOMC meeting, the money stock expanded at an 11 percent annual rate. $^{\theta}$ Also, during the intermeeting period, the prime rate at most large commercial banks rose from $8^{3 / 4}$ percent to 10 percent.

The range of tolerance for $M_{1}$ for the April-May period was 3 to 7 percent, which was lower than the band set for $M_{1}$ for the March-April period. The range for $M_{2}$ was $5^{1 / 2}$ to $8^{1 / 2}$ percent. A one percentage point range was adopted for Federal funds, with the upper limit at $10^{3 / 4}$ percent. "The longer-run growth rate for $M_{1}$ accepted by the Committee was revised upward slightly. ..."

"Subsequent to the meeting it appeared that in the April-May period the annual rates of growth in the monetary aggregates would be above the upper limits

${ }^{6}$ Compounded annual rate of change for the 4 weeks ending February 13 to the 4 weeks ending April 10. 
Date of Meeting

fatuary 21-22 In light of the foregoing developments, it is the policy of the Federol Open Market Com miltee to foster financial conditions conducive to resisting inflationary pressures, cushioning the effects on production and employment growing out of the oil shortoge, and mainof poyments.

\section{Operating Instructions}

To implement this policy, while laking atcount of the forthcoming Treasury financing and of infernational and domestic financial market developments, the Committee seeks to achieve bank reserve and money morket candifions consistent with moderate growth in monelary aggregales over the months ahead.

\section{Dissents}

Mr. Hayes and Mr. Francis indicated that they favored no change in the Commitfes's longer-run objectives for growth in the monelary aggregates..
February 20

- to foster financial conditions conducive to resisting inflationary pressures, cushioning declines in production and employment the are being induced in large part by the oil coenc's bolance of parments.
- while taking account of internotionat and domestic financial market developments, the Commiltee seeks to achieve bank reserve and money market conditions con sistent with moderate growth in monetary aggregates
Messrs. Buther, Morris, and Sheehan expressed concern about current and prospective weakness in aggregate economic demands. .... Mr. Francis expressed the view
March $18-19$

to foster financial conditions condueive to resisting inflationary pressures, supporting a resumption of real economic growth, and main taining equilibrium in the country's balonce of poyments.
... while taking account of infernational and domestic financial market developments, including the prospective Treasury financing the Committee seeks to achieve bonk reserve and money he Com conditions that would mo bank growth in monelary aggregates over the months ahead.
NONE

- While taking account of the forthcoming Treasury financing and of international and domestic financial bank reserve and money market condifions that would moderate growth in monetary aggregates over the months ahead.
May 21 . To foster financial conditions conducive to resisting inflationary pressures, supporting a resumption of real economic growth, and ochies ing equilibriu
.. While taking account of developments in domestic and international financial markets, the Committee seeks to mainfain about the prevailing restrietive money marke condilions, provided that the monetary aggregates appear tolerance.
NONE

NONE
June 18

NO CHANGE
While taking account of developments in domestic and international financiol markets, the Committee seeks to mainfain about the prevaling restrictive money market to mainfain about the prevaling pestrictive money market canditions, provided that the monetary aggregates appear tolerance.
Mr. Clay dissented from this action because he thought that for too tong the Committee had accepted rates of growth in the monetary aggregales that would result in a continuing and growing intation.

Absent and not yoting: Mr. Hayes. (Mr. Debs voted as alternate for Mr. Hayes I 
.. While foking account of the forthcoming Treasury refunding and of developments in domestic and international finoncial merkels, the Conmitree seeks to achieve bank reserve and moderate growth in monetary aggregates over the months
ahead.
-. Mr. Buther said he favored maintaining a gen erally restrictive policy stance in order to combar inflation. However, he thought that that longer-fun objective would be best served by seeking in the shon run to maintain growth in the monetary aggregates at recent pates; in his view, further efforts to thoderat monetary growth at this point would involve an un duly high hisk of ceating economic conditions the would necessitate a marked relaxation of policy.

Absent and not voting: Mr. Brimmer.
August 20 NO CHANGE

Seplember 10 NO CHANGE

October

NO CHANGE

$14-15$ and international finantial markets, the Committe seeks while taking account of developments in domestic to achieve bank reserve and money markel conditions consistent with moderate growth in monetary aggregates over the months ahead.

. While taking account of developments in domestic and international financial markets, the Committee seeks to achieve bank reserve and money morkef condifions consistent with moderate growth in monetafy dgoregates

. Whtle taking account of the forthooming Treasury financing and of developments in domestic and international financial markets, the Cammittee seeks to achieve bank reserve and money market conditions consisfent with resumption of moderale growth in monetary aggregates over the months aheod.
NONE

Absent and not roting: Mr. Brimmer.

Mr. Hayes... observed that inflation and inflationary expectotions continued unabated whereas the probabilities, in his view, were against the development of a severe recastion.

Mr. Clay ... expressed the opinion that the recent shorifalls in growth of $M_{1}$ were not due entirely to the weakness in economic activity but were, at leas in part, a lagged response to the high levels of short-term interest rates prevaling in the spring.

November 19 NO CHANG:

while taking account of developments in domestic and international financial markets, the Committee seeks to achieve bonk reserve and money morket conditions consistent with moderate growth in monetary aggregates over the months ahecd.

\section{December}

16.17
- . to foster financial conditions conducive to resisting inflationary pressures, cushioning recessionary tendencies and encouraging resumption of real economic growth, and achievpayments.
.. while taking account of developments in domestic and international financial markets, the Committee seeks to achieve bank reserve and money market conditions consistent with somewhat mope rapid growth in monetary aggregates over the months ahead than has accurred in

\section{NOME}

Mess's. Mitthell and Wallich ... both believed thot the economic sifuation and outlook called for a mor sfimulative monetary policy. 
of the ranges that had been specified by the Committee." During late April the rate at which Federal funds were trading seemed likely to exceed the range set at the April meeting and the System Account Manager reported that "in order to bring the funds rate back within the range of tolerance he would have to expand reserve-supplying operations, thus stimulating further growth of the monetary aggregates."

On April 24, in view of the continued pressure in the money market, and given the increase in the discount rate announced that day by many Reserve Banks, a majority of the Committee concurred in the Chairman's recommendation to raise the upper limit of the Federal funds constraint $1 / 4$ percentage point to 11 percent. Then, on May 17 "Chairman Burns recommended that the Committee take note of the difficulties faced by the System Account Manager in recent days and, in view of the likelihood that those conditions would persist over the next few days, that it change the ceiling guideline for the funds rate from 11 to $11^{1 / 4}$ per cent."

Between the April and May FOMC meetings, the prime bank loan rate increased 6 times, rising from 10 to 11.5 percent. Interest rates on commercial paper and large CDs also rose substantially during the intermeeting period. The steady rise in interest rates, which began in late February, continued despite an increase in the money stock at an 8.7 percent annual rate in the three months immediately preceding the May meeting. T" Member bank borrowings increased almost $\$ 1.5$ billion in the two weeks prior to the May meeting. ${ }^{8}$

The Federal funds constraint adopted at the May meeting permitted only a one-half of one percentage point variance. The Committee "decided that - in view of the sensitive state of financial markets and the considerable tightening in money market conditions that had occurred over recent months - greater emphasis than usual should be placed on money market conditions during the period until the next meeting ...."

A staff analysis at the May meeting suggested that "the maintenance of prevailing money market condi-

TCompounded annual rate of change for the 4 weeks ending February 13 to the 4 weeks ending May 15 .

8 In hearings before the Committee on Banking and Currency of the House of Representatives in July 1974, Alfred Hayes President of the Federal Reserve Bank of New York, stated "taking the period from mid-May to mid-July, System open market operations added approximately $\$ 1.2$ billion to reserves and coincidentally Franklin's borrowings from the Fedcral Reserve Bank increased in about the same order of inagnitude."

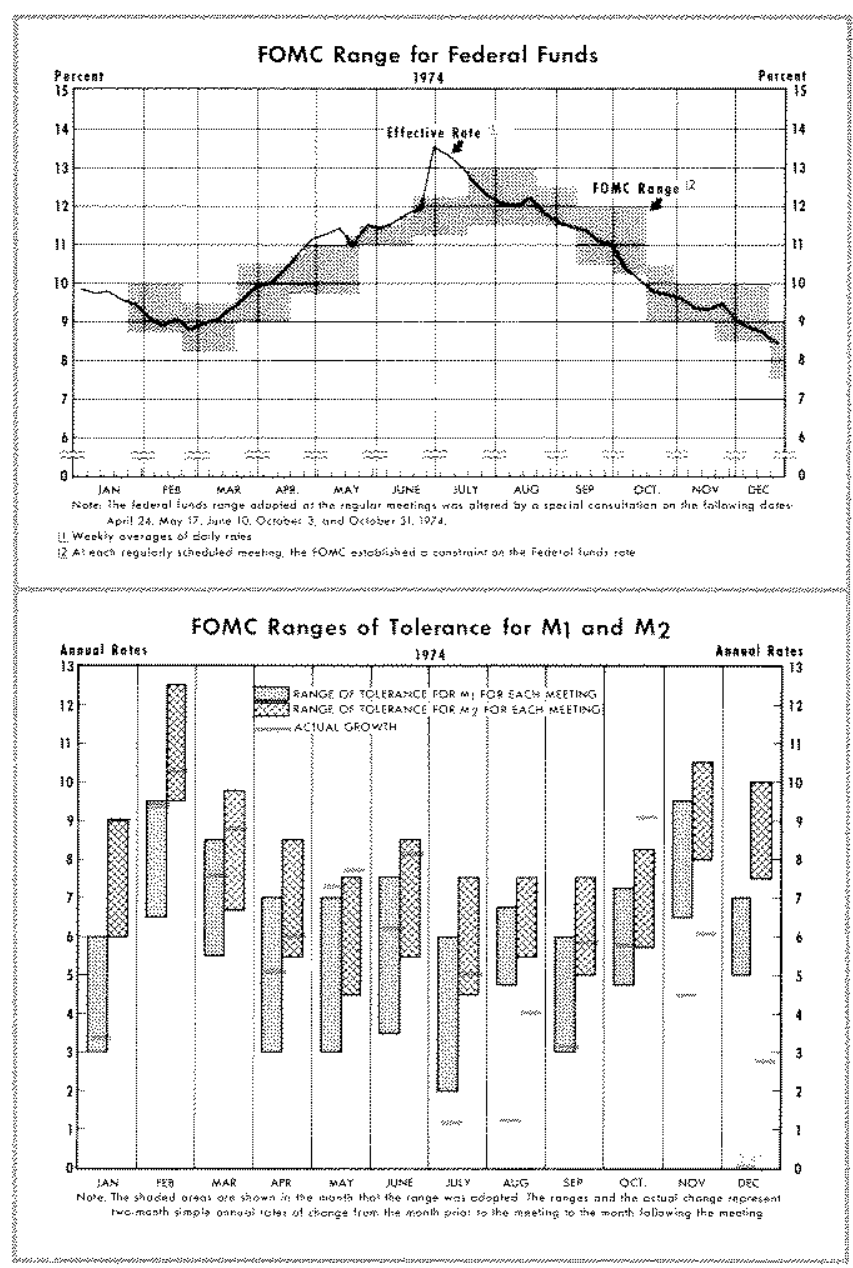

tions would be associated with a dampening in the rate of growth of money because the demand for money was likely to be restrained by the lagged effects of the sharp rise in short-term market rates of interest" that had occurred recently. The Federal funds range was widened to $3 / 4$ percentage point on June 10 , as the upper limit was raised to $11^{3 / 4}$ percent.

At the June meeting, the staff observed that the existing money market conditions "would be associated with some slowing in the rate of growth of the narrowly defined money stock over the months ahead, because the demand for money was likely to be restrained by the lagged effects of the rise in short-term market rates of interest that had occurred over the past few months." In view of these conditions the Federal funds rate was allowed to vary between $11 \frac{1 / 4}{4}$ percent and $121 / 4$ percent in the period until the next meeting. The ranges of tolerance adopted for $M_{1}$ and $\mathrm{M}_{2}$ for the June-July period were $3^{1 / 2}$ to $7 \frac{1 / 2}{1 / 2}$ percent and $5 \frac{1 / 2}{1}$ to $8 \frac{1}{2}$ percent, respectively.

During the first half of 1974, the accompanying charts indicate that the FOMC was successful in 
achieving both the Federal funds rate and money growth targets. The error in May in the aggregates was very slight, especially when the four data revisions curing the year are considered. Also during May, the Federal funds rate slightly exceeded its range. The notable error in achieving the Federal funds target came in late June and early July, but the Committee tolerated this deviation. In a telephone consultation on July 5 the Committee noted the Manager's report that "... the high level of the funds rate was a reflection of the great uncertainty prevailing in both domestic and foreign financial markets, compounded by the effects of market transactions related to the midyear statement date for banks and by the July 4 holiday. In view of the likelihood that the high level of the rate was primarily a consequence of technical factors that might well prove temporary, the Committee concluded that there was no immediate need to press hard to bring the funds rate down within the specified range of tolerance."

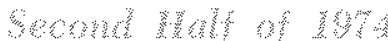

Chairman Arthur Burns commented before the Joint Economic Committee in early August that "clearly, the American economy is not being starved for funds. On the contrary, growth of money and credit is still proceeding at a faster rate than is consistent with general price stability over the longer term." Based on current data, the growth of the money stock was at a 10.9 percent annual rate during June. According to the "Record of Policy Actions" a major part of the step-up was attributable to a temporary increase in foreign official deposits arising from payments to oil exporters. ${ }^{9}$

At the August meeting, "a staff analysis suggested that the unusually slow pace of monetary growth in July was not likely to persist in view of the continued sizable rate of growth in prospect for nominal GNP; in fact, data available for early August indicated that some strengthening had occurred already." The range of tolerance for $M_{1}$ and $M_{2}$ was only 2 percentage points for the August-September period, compared with the 4 percentage point spread for $M_{1}$ during the July-August period.

The Board of Govemors announced on September 4 the removal of its 3 percent marginal reserve requirement on certificates of deposit in denominations of $\$ 100,000$ or more with maturities of four months or

\footnotetext{
As stated, this statement implies that domestically-owned U. S. demand deposits did not simuttaneously decline as a result of the transactions with foreign oil producers.
}

longer. The action reduced the volume of required reserves by about $\$ 400$ million.

Although many of the economists at the White House Summit Conference in early September called for monetary ease, Edwin L. Dale, Jr., of the New York Times reported that "high Federal Reserve officials have gone out of their way to point out, for the first time, that the Reserve's highly restrictive monetary policy has already been eased to a significant degree, and they add that no 'substantial' further easing is to be expected." The money stock grew at a 1.5 percent annual rate from June to August compared to the 6.7 percent growth in the first half of the year. The ranges for $M_{1}$ and $M_{2}$ were 3 and $21 / 2$ percentage points wide, respectively, for the September-October period. The Federal funds range established at the September meeting was less than the range established at the August meeting.

At the October meeting the one-month range of tolerance for the Federal funds rate was lowered considerably, and the October-November ranges for $M_{1}$ and $M_{2}$ were somewhat higher than the ranges set for the September-October period. In November the two-month ranges of tolerance for the aggregates were somewhat higher than they were in October. Throughout the last three months of 1974, the onemonth range of tolerance for the Federal funds rate was reduced.

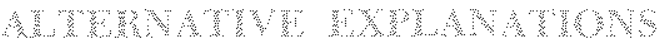

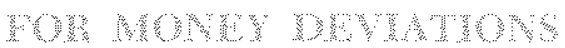

The growth rates of both $M_{1}$ and $M_{2}$ were within the desired ranges in only one month during the second half of the year. The Federal funds rate, however, followed closely the ranges established at each meeting (see accompanying charts).

There are two alternative, but not necessarily in consistent, reasons for the frequent failure of the growth rates of $\mathrm{M}_{1}$ and $\mathrm{M}_{2}$ to be within their specified ranges last year. One reason was the complication of having a Federal funds constraint as well as a monetary aggregate growth target. The other was an unanticipated change in the relationship of the growth of $M_{1}$ and $M_{2}$ to growth of the monetary base.

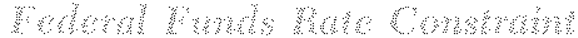

The problem created by having specified ranges of tolerance for both the monetary aggregates and the Federal funds rate is illustrated in Figure I. Line I represents a hypothetical projected relationship be- 
tween the Federal funds rate and the associated rate of change in money made by the FOMC staff and considered in the Committee's deliberations. ${ }^{10}$ This relationship is based mainly on a projection of growth of GNP. According to the relationship, given the projected growth of GNP, the level of the Federal funds rate and the growth of money are inversely related.

For illustration, assume that the consensus of the meeting is that a Federal funds rate between 6 and 7 percent will be sought. According to the projected relationship this implies that the growth of money during the two-month interval will be between 5 and 8 percent. Assuming that such a range of money growth is deemed acceptable, open market operations which maintain the Federal funds rate within its range would be expected to result in money growth within its range of tolerance.

A problem associated with this approach is that the projected relationship between alternative Federal funds rates and associated growth rates of money (Line I) is not known with certainty. Suppose that the actual growth of GNP is not as high as projected, and that the actual growth would yield a set of relationships represented by Line II. If such were the case, adherence to the 6 percent lower limit for the Federal funds rate would be expected to result in only a 2 percent rate of money growth -3 percentage points below its lower range of tolerance. Or, adherence to the 5 percent lower limit for growth in money would be expected to result in a 5 percent Federal funds rate, which is less than its lower limit of tolerance. In such a situation, a choice must be made regarding which range of tolerance is to be achieved.

The existence of such a situation, as depicted in Figure I, may account in part for the failure of money growth rates to be within their ranges of tolerance in the second half of 1974. Most forecasters did not project the decrease in the rate of growth of GNP, with the result that a wrong projection would be made of the money market relationships. Consequently, a choice had to be made regarding which of the two ranges of tolerance was to be achieved. The actual outcome was achievement of a Federal funds rate within its' range, but the monetary aggregates were outside of their ranges.

\footnotetext{
10This relationship is discussed in Stephen H. Axilrod and Darwin L. Beck, "Role of Projections and Data Evaluation with Monetary Aggregates as Policy Targets," Controlling Monetary Aggregates II: The Implementation, Federal Reserve Bank of Boston, pp. 81-102.
}

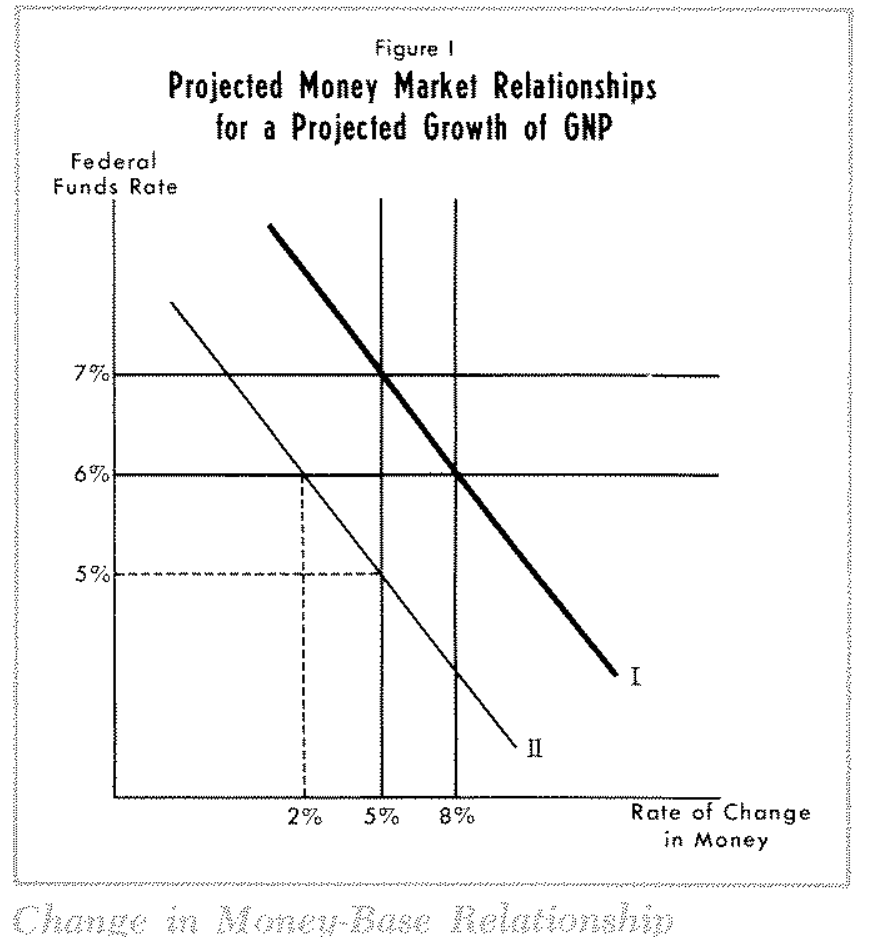

Normally, the growth of the money stock is about the same as the growth of the monetary base over periods of one year or more, but in 1974 the 5.3 percent growth of money was considerably slower than the 8.4 percent growth of the base. ${ }^{11}$ Part of the divergence in these rates of growth can be attributed to the 15 percent growth of time deposits during the year. When reserves are supplied to the banking system, they may be used to support either time or demand deposits. The expansion of time deposits in $1974 \mathrm{ab}$ sorbed a large volume of reserves, leaving fewer reserves available to support an expansion of demand deposits. Some growth in time deposits occurs regularly, but the more-rapid than-usual growth of time deposits in 1974 resulted in a smaller-than-expected multiplier between monetary base and the money stock.

An additional factor contributing to the discrepancy in the growth rates of the monetary base and the money stock was the exceptionally large increase in the volume of currency held by the public. Although the money stock increased only about 5.3 percent in 1974, the currency component increased almost twice as fast as $M_{1}$, while demand deposits grew at only a 3.9 percent rate.

Currency is the largest use of monetary base and, by itself, has a multiplier of unity in "creating money."

"Percentages were calculated from fourth quarter 1973 to folrth quarter 1974. 


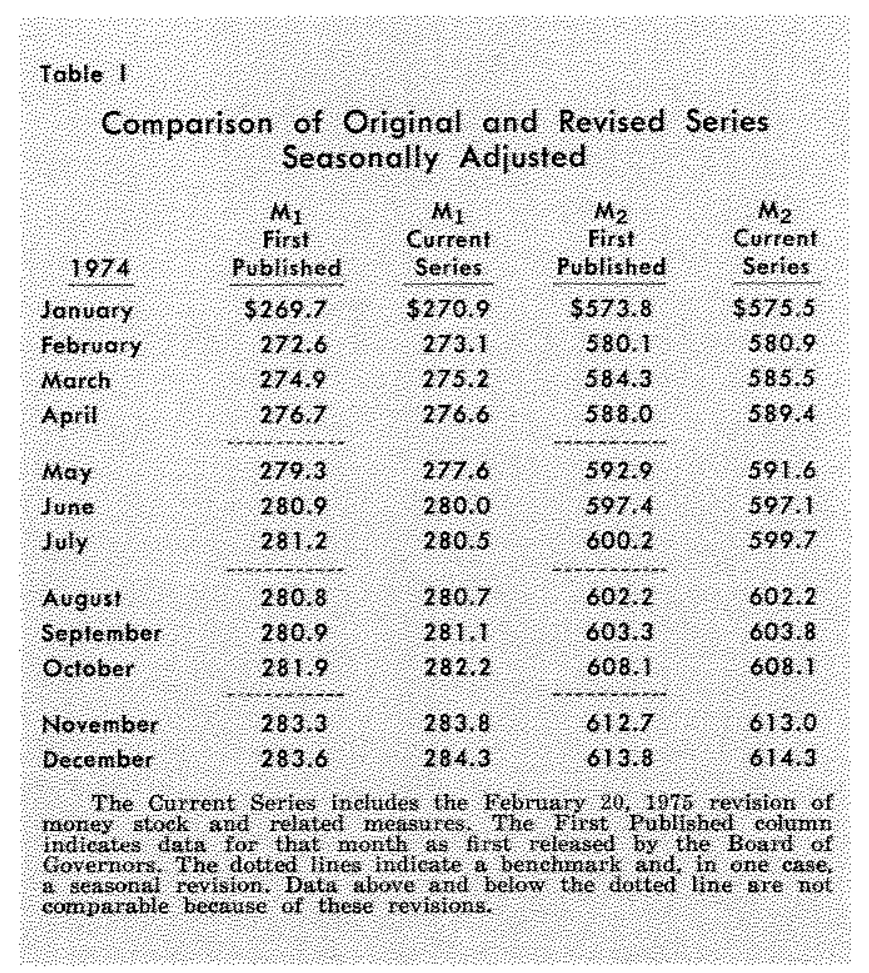

A dollar increase in the monetary base that is matched by a dollar increase in currency also increases the money stock (currency plus demand deposits), but only by one dollar. An increase in currency creates no multiple expansion between monetary base and the money stock. To the extent that the extraordinary increases in currency and the resulting fall in the multiplier were unanticipated last year, growth of money was less than one would have expected.

\section{Bमn Barm:}

A purely technical uncertainty regarding growth of the money stock also occurred last year. This uncer tainty stems from the fact that data on the money stock were revised four times during 1974. Policymakers took actions based on the reported growth of the money stock, but later revisions in the data may have indicated different conclusions than preliminary figures. One major source of revision in the data on the money stock is that actual nonmember bank data are available only four times a year, and must be estimated during the remainder of the year. Table I presents the revisions in the money stock data for 1974.
Few, if any, economic analysts foresaw the 5 percent decline in real output which occurred during 1974. Few predictions in late 1973 indicated a 12 percent increase in prices or over a 7 percent unemployment rate by year's end. The FOMC staff did no worse of a job projecting economic activity than most private forecasters. Controversies and uncertainties existed last year regarding the appropriate growth of monetary aggregates. Those who viewed the downturn as demand-induced recommended faster money growth, while others, who viewed the recession as supplyinduced and recognized the seriousness of accelerating inflation, argued for slower money growth.

In the first half of last year $M_{1}$ increased at a 6.7 percent rate and $M_{2}$ at a 9.3 percent rate. The Federal funds rate increased during the same pexiod from 9.65 percent in January to 11.93 percent in June, on a monthly average basis. The growth of the monetary aggregates and the rise in the Federal funds rate were almost consistently within the ranges of tolerance specified by the FOMC.

In the second half of 1974, the rates of growth for $\mathrm{M}_{1}$ and $\mathrm{M}_{2}$ were 3.9 and 6.5 percent, respectively. The Federal funds rate fell from 11.93 percent in June to an average of 8.53 percent in December. The growth rates of the monetary aggregates were, for the most part, well below the FOMC two-month ranges of tolerance, while the Federal funds rate again was almost always within the specified ranges.

Even in retrospect, analysts are uncertain as to how to evaluate monetary policy last year. Such an evaluation depends on the measure used as an indicator of the influence of policy on the economy. Those who believe that the Federal funds rate is a good indicator concluded last year that the thrust of policy was rem strictive in the first half, but less so in the second half. On the other hand, those who use growth of money as an indicator would conclude that monetary actions were expansionary in the first half and restrictive in the second.

Last year was unlike any previous year. Inflation and recession both became more severe than anyone foresaw early in the year. With the array of different analyses that existed, it is only fitting that 1974 be labelled the "year of uncertainty". 